\title{
Development and optimization of an indirect enzyme-linked immunosorbent assay for 19-nortestosterone*
}

\author{
Zh. Tian', D.H. Yu ${ }^{1}$, Y.Y. Zhang ${ }^{2}$, J.H. Guo ${ }^{1}$, Ch.F. Peng ${ }^{1}$, \\ Zh.X. Chen ${ }^{1,3}$ and Ch.L. Xu ${ }^{1,3}$ \\ ${ }^{1}$ Department of Food Science and Technology, Southern Yangtze University \\ 170 Huihe Road, WuXi 214036, Jiangsu Province, P.R. China \\ ${ }^{2}$ Department of Biological Engineering, Southwest Jiaotong University \\ Chengdu 610031, Sichuan Province, P.R. China
}

(Received 23 June 2007; revised version 11 December 2007; accepted 8 April 2008)

\begin{abstract}
A polyclonal antibody-based enzyme-linked immunosorbent assay (ELISA) has been developed, optimized and validated to measure this anabolic steroid. Influence of several physicochemical parameters, such as incubation time, ionic strength, detergent concentration and $\mathrm{pH}$ were selected to provide a highest sensitivity on the ELISA format. The regression equation of the final inhibition curve was: $y=-0.3194 x+1.6316, R^{2}=0.9927$. The linear range was between 0.1 and $25 \mathrm{ng} / \mathrm{ml}$ and the $\mathrm{IC}_{50}$ was $3.5 \mathrm{ng} / \mathrm{ml}$. The specificity was evaluated by five structurally related anabolic steroids, and none of them had significant cross-reactivity. Finally, the accuracy and precision of this assay were evaluated by means of spiked samples. The recovery was between 76.9 and $104.7 \%$, and the variation coefficient was between 5.2 and $13.4 \%$.
\end{abstract}

KEY WORDS: 19-nortestosterone, ELISA, immunoassay

\section{INTRODUCTION}

19-Nortestosterone, also called nandrolone (NT), one of the most powerful anabolic steroids, has been widely used in veterinary as well as human medicine for the treatment of protein deficiency diseases, osteoporosis and male contraception (Hobbs et al., 1996; Kuhnz and Gieschen, 1998; Bruggeman et al., 2003; Meriggiola

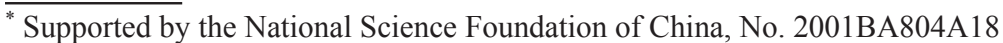

${ }^{3}$ Corresponding author: e-mail: ZXCHEN@jiangnan.edu.cn; XCL@sytu.edu.cn
} 
et al., 2003). Nandrolone has also been employed as a growth-promoting agent to accelerate weight gain, improve feeding efficiency in meat producing animals and as a doping agent to boost muscular strength and performance in sports and horse racing (Kim et al., 2000; Kohler and Lambert, 2002).

As their possible harmful effects result from the intake of hormone residues and their metabolites, usage of growth-promoting drugs for fattening livestock have been banned in many countries. However, illegal use of 19-nortestosterone as a growth promoter has been widely reported in many countries (Draisci et al., 2000; Le Bizec et al., 2000). Thus, it is necessary to control 19-nortestosterone's abuse.

Conventional chromatographic methods, such as gas chromatography (GC) or liquid chromatography (LC) coupled with mass spectrometry (MS) and tandem mass spectrometry (MS-MS), are used as confirmatory methods because of the high specificity of the information from the analyte (Le Bizec, 1999; Reznik et al., 2001; Robinson et al., 2001; Marcos et al., 2004). But those methods are time-consuming and expensive when large number of samples is detected. Thus, radioimmunoassay and enzyme immunoassays, which based on immunoassay, have been widely used for routine screening for their cost-effective and fieldportable (Degand et al., 1989; Cooper et al., 2001).

Some authors (Evrard et al., 1986; Van Look et al., 1991; Roda et al., 2003) have reported the preparation steps of the antibodies for the small molecule immunizing hapten (oximation, conjugation, immunization, etc.). However, the development and optimization of the indirect enzyme-linked immunosorbent assay for 19-nortestosterone has not been reported yet. An indirect competitive ELISA assay for the measurement of NT has been developed and its optimization also been reported in this article. The concentration of the immunoreagents and the influence of incubation time, ionic strength, detergent concentration and $\mathrm{pH}$ were selected to provide the highest sensitivity on the indirect ELISA format.

\section{MATERIAL AND METHODS}

\section{Reagents and chemicals}

Bovine serum albumin (BSA, electrophoretic grade) and ovalbumin (OVA, electrophoretic grade) were purchased from Boao Biotechnology Company (Shanghai, China); 19-nortestosterone, testosterone, medroxyprogesterone, complete Freund's adjuvant (FAC), incomplete Freund's adjuvant (FAI) were purchased from Sigma (St.Louis, USA). Epitestosterone, dehydroepiandrosterone and progesterone were kindly gifted by Chinese Academy of Inspection and Quarantine; goat anti-rabbit immunoglobulin conjugated to horseradish peroxidase 
(HRP) and Tween-20 were obtained from Shanghai KangChen Bio-tech; isobutyl chloroformate, N, N-dimethylformamide and tri-n-butylamine were obtained from Feixiang Chemical Plant (Shanghai, China); 3,3',5,5'-tetramethylbenzidine (TMB) was purchased from Longyou Chemical Company (Zhejiang, China).

\section{Apparatus}

Polystyrene microtiter plates were purchased from Nunc (Roskilde, Denmark); MuLtiska Mks microplate reader was purchased from Thermo Labsystem (Helsinki, Finland); the LC/MS spectrometer (Waters Platform ZMD 4000) was obtained from Waters Company (Milford, MA), the shaker from Taicang Science and Education Equipment Company, UV-2100 UV scanner from Ruili Company (Beijing, China) and PHS-3TC $\mathrm{pH}$ meter from Shanghai Tianda Apparatus Company.

\section{Buffer and solutions}

The assay buffer was $0.01 \mathrm{M}$ phosphate buffer, and if not indicated otherwise, the $\mathrm{pH}$ was 7.5 . Coating buffer was $0.05 \mathrm{M}$ carbonate-bicarbonate buffer, $\mathrm{pH}$ 9.6. The buffer PBST was PBS with $0.05 \%$ Tween 20. Citrate buffer was $0.15 \mathrm{M}$ sodium citrate in water at $\mathrm{pH} 5.5$. Antibody dilution buffer was $0.1 \%$ gelatin in PBS. The chromogen solution was 3,3',5,5'-tetramethylbenzidine (TMB 0.42 $\mathrm{mg} / \mathrm{ml})$ in glycol and the substrate solution was $\mathrm{H}_{2} \mathrm{O}_{2}(0.006 \%)$ in citrate buffer. Enzymatic reaction is stopped by $2 \mathrm{M} \mathrm{H}_{2} \mathrm{SO}_{4}$.

\section{Standard solutions and sample preparation}

Nandrolone $(52 \mathrm{mg}$ ) standard solutions were dissolved in $100 \mathrm{ml}$ dehydrated alcohol and then diluted with PBS buffer containing $10 \%$ methanol to provide a series of standards solutions of NT $(0,0.1,0.3,0.9,2.7,8.1,25 \mathrm{ng} / \mathrm{ml}$.)

19-Nortestosterone is illegally used as a growth promoter in pig raising in China. In order to determine the content of 19-nortestosterone in pork, normal and wellmuscled cattle presented for slaughter at local meat plants were purchased. Fat and connective tissue in the sample was removed, and then the sample was homogenized. Exactly $2 \mathrm{~g}$ of the sample was distributed into $6 \mathrm{ml}$ PBS buffer containing $10 \%$ methanol, followed by carbonate-bicarbonate buffer $(6 \mathrm{ml})$ and ethyl acetate $(10$ $\mathrm{ml}$ ). The mixtures were shook vigorously for $30 \mathrm{~min}$, and then centrifuged at 4000 $\mathrm{rpm}$ for $10 \mathrm{~min}$. The supernatant was pipetted into another centrifugal screw-cap vial and evaporated to dryness under a gentle nitrogen stream. The residue was dissolved in $100 \mu \mathrm{l}$ of methanol by ultrasonication for $30 \mathrm{~s}$, and $900 \mu \mathrm{l}$ PBST was added following. The solution was employed in the ELISA assay. 


\section{Steroid conjugate production}

The 19-nortestosterone-3-carboxymethoxylamine conjugate (19-NT-3-CMO) was prepared as follows. To a solution of 19-nortestosterone $(27 \mathrm{mg})$ in dry pyridine $(10 \mathrm{ml})$, carboxymethoxylamine hemihydrochloride $(219 \mathrm{mg})$ was added. The pyridine was removed by vacuum distillation at $50^{\circ} \mathrm{C}$ for $30 \mathrm{~min}$. Then the residue was dissolved in ethyl acetate $(50 \mathrm{ml})$. The organic layer was washed four times with distilled water $(20 \mathrm{ml})$, dried with anhydrous sodium sulphate, and then removed by vacuum distillation. After that, the resulting white foam was recrystallized with diethyl ether, and then 19-NT-3-CMO as a white powder $(210 \mathrm{mg})$ was obtained. The scheme of steroid conjugate production was shown on Figure 1. The oximated production was characterized by mass spectrum.

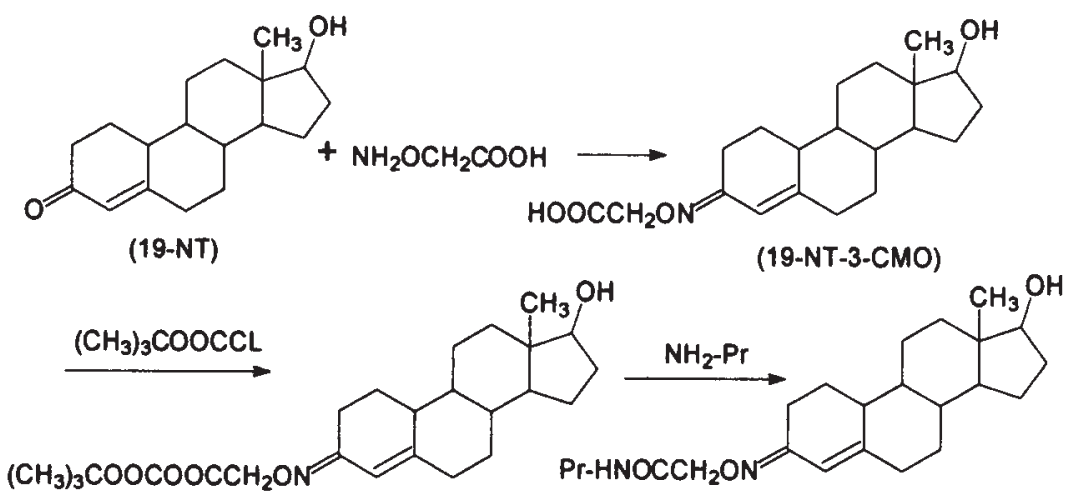

(19-NT-3-CMO-Pr)

Figure 1. Synthetic pathway used for the preparation of steroid conjugate (19-NT-3-CMO-Pr)

The immunogen (19-NT-3-CMO-BSA) and the coating conjugation (19-NT3-CMO-OVA) were prepared by mixed-anhydride method. $100 \mathrm{mg}$ of 19-NT-3$\mathrm{CMO}$ was dissolved in $1 \mathrm{ml} \mathrm{N}, \mathrm{N}$-dimethylformamide (DMF) and tri-n-butylamine $(15 \mu \mathrm{l})$ was added in together with isobutyl chloroformate $(45 \mu \mathrm{l})$ at $4^{\circ} \mathrm{C}$ for $2 \mathrm{~h}$. To a solution of protein (BSA:218 mg, OVA:120 mg) in $2 \mathrm{ml}$ PBS, DMF (1 ml) was added and stirred at $4^{\circ} \mathrm{C}$ for $1 \mathrm{~h}$. With gentle stirring, the active hapten was slowly dripped into the protein solutions. The reaction mixture was stirred at $4{ }^{\circ} \mathrm{C}$ for $4 \mathrm{~h}$, then dialysed against distilled water. The NT conjugates were aliquot into $100 \mu 1$ volumes and stored at $-20^{\circ} \mathrm{C}$.

\section{Immunization protocol}

New Zealand white rabbits (one-month-old) were immunized subcutaneously various sites with $1 \mathrm{mg}$ of the conjugate in water emulsified with complete Freund's 
adjuvant, with booster injections being given at 3 week intervals in incomplete adjuvant. Test blood was withdrawn from the marginal ear vein and monitored for the presence of antibodies, every 7 days after each booster injection. Antiserum R1, R2, R3, R4 and R5 with adequate titer, affinity and specificity was obtained 3 months after the first immunization. The serum was harvested 7 days after the last booster injection, the serum with eqal volume of glycerol was aliquoted, and stored at $-20^{\circ} \mathrm{C}$. All animal experiments have a permission of Jiangsu Animal Management Committee in China.

\section{ELISA procedure}

Microtiter plates were coated with 19-NT-3-CMO-OVA(from 1/1000 to 1/32,000, in coating buffer, $100 \mu \mathrm{l} /$ well) for $2 \mathrm{~h}$ at $37^{\circ} \mathrm{C}$. Then, the plates were washed three times with PBST ( $200 \mu \mathrm{l} /$ well, $3 \mathrm{~min}$ ), and blocked with OVA ( $2 \%$ in PBS, 200 $\mu \mathrm{l} /$ well) for $2 \mathrm{~h}$ at $37^{\circ} \mathrm{C}$. Plates were washed as described above and $100 \mu \mathrm{l}$ aliquots of the mixture of NT 0 standard and the diluted serum (from 1/1000 to 1:128,000, in antibody dilution buffer) was added and incubated for $30 \mathrm{~min}$ at $37^{\circ} \mathrm{C}$. The plates were washed again, and a solution of goat anti-rabbit IgG-conjugated to HRP (anti IgG-HRP, 1/3000 in antibody dilution buffer), was added (100 $\mu \mathrm{l} /$ well) and incubated for $30 \mathrm{~min}$ at $37^{\circ} \mathrm{C}$. After washing, $100 \mu \mathrm{l}$ mixture of the chromogen and the substrate $(1: 10, \mathrm{v} / \mathrm{v})$ was added and incubated for 15 to $30 \mathrm{~min}$ at $37^{\circ} \mathrm{C}$ before the enzymatic reaction was stopped by adding $2 \mathrm{M} \mathrm{H}_{2} \mathrm{SO}_{4}(100 \mu \mathrm{l} /$ well). The absorbance was read at $450 \mathrm{~nm}$ by a MuLtiska Mks microplate reader.

\section{Optimization of the ELISA method}

A set of experimental parameters (incubation time, ionic strength and $\mathrm{pH}$, detergent concentration, etc.) was studied sequentially to improve the immunoassay sensitivity, and study the immunoassay performance under several conditions (Oubina et al., 1999).

These experiments were carried out using the indirect protocol described above. In this case, seven NT standards (from 0 to $25 \mathrm{ng} / \mathrm{ml}$ ) added duplicates were used to prepare calibration curves. The coating antigen NT-OVA diluted to $1 / 8000$ in coating buffer and the antiserum diluted to $1 / 8000$ in antibody dilution buffer were the immunoreactive chosen as already described. On the same plate, each curve varied on one of the investigated parameters. The best experimental conditions on each step were chosen to evaluate the next parameter in the following order.

The NT standard solutions and the diluted serum were aliquot added and incubated in each well. On each microtiter plate, the mixtures were incubated for different periods $(10,20,30,40,50,60,90 \mathrm{~min})$ at $37^{\circ} \mathrm{C}$. Finally, the plates were washed and processed as already described. 
Different concentrations of PBS $(0.05,0.02,0.01,0.005 \mathrm{M})$ were prepared and used to dilute the antibody. The different competitive experiments were studied in the same microtiter plate.

PBS buffers ranging from $\mathrm{pH} 2.5$ to $\mathrm{pH} 10.5$ were used to prepare solutions of the immunoassay and to carry out the competitive immunoassay. PBS buffer containing different concentrations of Tween $20(0.2,0.1,0.05,0.005,0.001$, $0.0005, \%)$ were used to wash the plates in the competitive ELISA.

The diluted serum and NT standard solutions were added and incubated at different volume ratio $(70 / 30,60 / 40,50 / 50,40 / 60,30 / 70, \mathrm{v} / \mathrm{v}, 100 \mu \mathrm{l} / \mathrm{well})$. On each microtiter plate, the mixtures were incubated for $30 \mathrm{~min}$ at $37^{\circ} \mathrm{C}$.

The antibody dilution buffer containing different concentrations of goat antirabbit IgG, conjugated to $\operatorname{HRP}(1 / 1000,1 / 2000,1 / 3000,1 / 5000,1 / 800, \mathrm{v} / \mathrm{v})$, were added $(100 \mu \mathrm{l} /$ well $)$ and incubated for $30 \mathrm{~min}$ at $37^{\circ} \mathrm{C}$.

Different volume ratios of the chromogen and the substrate $(1 / 3,1 / 5,1 / 8,1 / 10$, $1 / 12, \mathrm{v} / \mathrm{v})$ were prepared and used in the chromogenic reaction step $(100 \mu \mathrm{l} /$ well $)$ at $37^{\circ} \mathrm{C}$.

The chromogen and the substrate were mixed as volume ratio described already. The mixtures incubated during different periods $(5,10,15,30,60 \mathrm{~min})$ at $37^{\circ} \mathrm{C}$. Finally, the enzymatic reaction was stopped by adding $2 \mathrm{M} \mathrm{H}_{2} \mathrm{SO}_{4}(100 \mu \mathrm{l} /$ well $)$ and the absorbance was measured at $450 \mathrm{~nm}$ with MuLtiska Mks microplate reader.

\section{Optimized competitive ELISA}

The final analytical procedure was as follows: microtiter plates were coated with 19-NT-3-CMO-OVA (1/8000, in coating buffer, $100 \mu \mathrm{l} /$ well) for $2 \mathrm{~h}$ at $37^{\circ} \mathrm{C}$ and then the plates were washed with PBST ( 3 times, $200 \mu 1 /$ well). The wells were blocked with OVA ( $2 \%$ in PBS) for $2 \mathrm{~h}$ at $37^{\circ} \mathrm{C}$. Then the plates were washed again, and the NT standards ( 0.1 to $25 \mathrm{ng}$, in PBST) or samples were added to the coated plates $(50 \mu \mathrm{l} /$ well), followed by the diluted antiserum $(1 / 8000$ in antibody dilution buffer, $50 \mu \mathrm{l} /$ well). After incubation $\left(30 \mathrm{~min}, 37^{\circ} \mathrm{C}\right)$ and washing steps, a solution of anti-IgG-HRP (1/3000 in antibody dilution buffer) was added $(100 \mu \mathrm{l} / \mathrm{well})$ and incubated for $30 \mathrm{~min}$ at $37^{\circ} \mathrm{C}$. After washing, the mixtures of chromogen and substrate were added $(1: 5, \mathrm{v} / \mathrm{v}, 100 \mu \mathrm{l} /$ well $)$ in the plates. The enzyme reaction was stopped after $15 \mathrm{~min}$ at $37^{\circ} \mathrm{C}$ with $2 \mathrm{M} \mathrm{H}_{2} \mathrm{SO}_{4}(100 \mu \mathrm{l} /$ well $)$ and the absorbance was measured at $450 \mathrm{~nm}$.

\section{Cross-reactivity}

Stock solutions of five steroids (testosterone, epitestosterone, progesterone, dehydroepiandrosterone and medroxyprogesterone) were prepared in methanol. Standard curves for each of these compounds were constructed (1.76 nM to 
$36 \mu \mathrm{M}$, in PBST) and their $\mathrm{IC}_{50}$ values were determined by the optimized ELISA. The cross-reactivity values were calculated according to the following equation:

Cross-reaction rate $(\%)=\mathrm{IC}_{50}(\mathrm{NT}) \times 100 \% / \mathrm{IC}_{50}($ aim chemical $)$

\section{Precision and accuracy}

The precision study was performed using bovine tissue samples spiked with NT at different concentrations ( 1 or $5 \mathrm{ng} / \mathrm{g}$ ). Analyses of these samples were performed in duplicates in separate plates over five different days. The values of the coefficients of variation were measured. Briefly, accuracy was determined by adding known amounts of standard NT dose (1 and $5 \mathrm{ng} / \mathrm{g}$ ) to bovine tissue samples as already described and all samples were assayed by the optimized ELISA and the recovery values calculated.

\section{RESULTS AND DISCUSSION}

The LC-MS of 19-nortestosterone and 19-nortestosterone-3-carboxymethoxylamine conjugate (19-NT-3-CMO) were shown in Figure 2. Two prominent fragment ions seemed to be generic to 19-nortestosterone, namely $\mathrm{m} / \mathrm{z} 274$ and 272. The major fragment ions at $\mathrm{m} / \mathrm{z} 348$ and 346 were thought to be a result from $\mathrm{MH}^{+}$and $\mathrm{MH}^{-}$for the 19-NT-3-CMO.

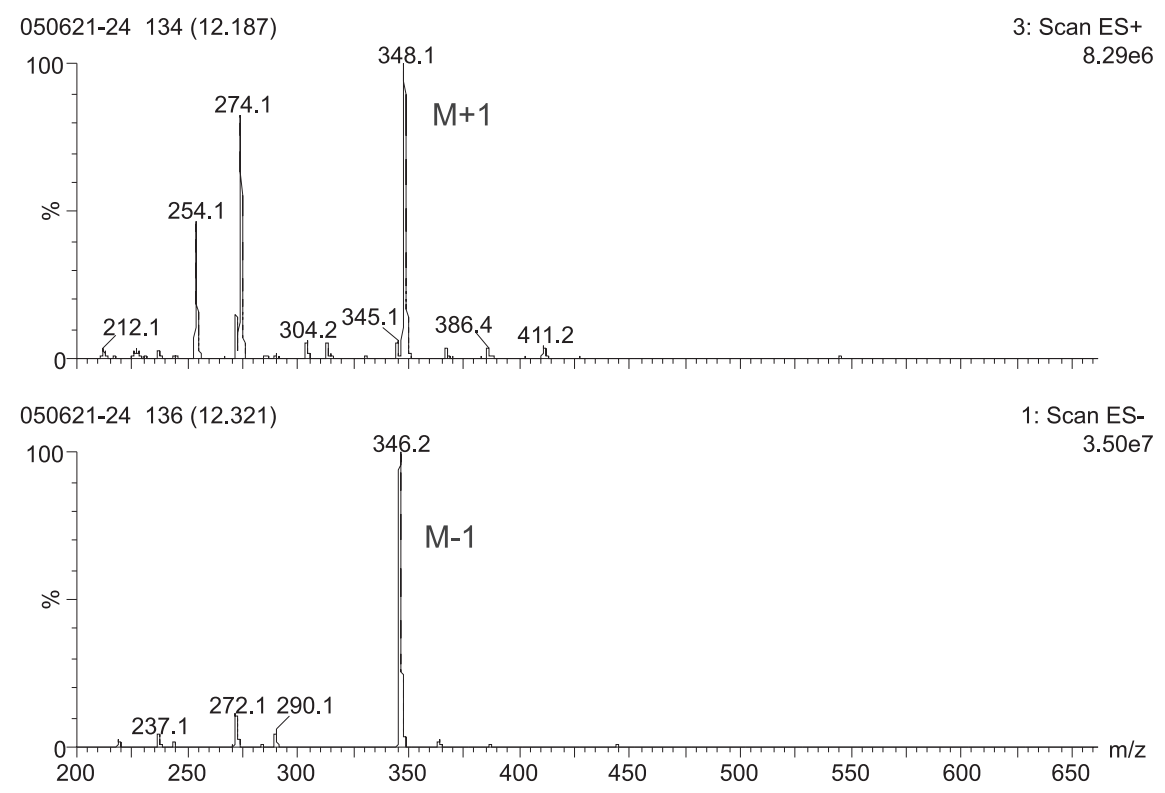

Figure 2. Determination results of the NT and its oximated production by MS 
Antiserum of the 19-NT-3-CMO-BSA was evaluated by indirect competitive ELISA. Antiserum titration, by definition, corresponds to the antiserum dilution resulting in uninhibited assay signal three times the background signal under given assay conditions. The titrations for R1, R2, R3, R4 and R5 were 1:51,200, $1: 25,600,1: 102,400,1: 204,800$ and 1:51,200, respectively, which indicated that the coupling of 19-NT-3-CMO-BSA was successful. As R4 displayed the highest titer, our subsequent experiments were carried out with the R4 antiserum.

The coated concentrations of 19-NT-3-CMO-OVA (from 1/1000 to $1 / 32,000$, in coating buffer) and the diluted serums (from 1/1000 to 1:128,000, in antibody dilution buffer) were evaluated by indirect non-competitive ELISA. The concentration corresponds to the dilution resulting in the $\mathrm{A}_{\max }$ at 1.5 under given assay conditions. For this reason, the optimum concentrations of the coating conjugate and the antiserum were both $1 / 8000$.

It has been reported (Oubina et al., 1999), the time given to the immunoreagents to interact, may have a direct effect on the sensitivity of the immunoassay. For this reason, the effect of the incubation time was studied. And the immunoassay features were readily influenced by the duration of the competitive step $(10,20,30,40,50$ and $60 \mathrm{~min}$ ). Figure 3 showed the variation of the $\mathrm{IC}_{50}$ and the maximal absorbance

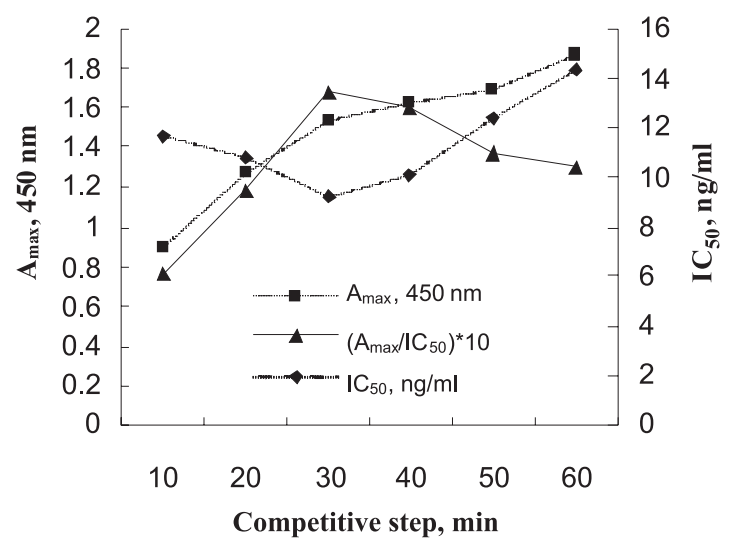

Figure 3. Influence of the length of the competitive step on $\mathrm{IC}_{50}$ and $\mathrm{A}_{\max }$ of the NT immunoassay

under the investigated conditions. An increase of the $\mathrm{IC}_{50}$ value was observed when varying the incubation time from $30 \mathrm{~min}$ to $1 \mathrm{~h}$. The maximum absorbance value of the assay also varied from 0.9 to 1.8 units when increasing the incubation time. As it can be observed in the Figure 3, 30 min of incubation was sufficient for adequate sensitivity of the assay without diminishing the signal $\left(\mathrm{A}_{\max } / \mathrm{IC}_{50}\right.$ ratio).

This parameter had a strong effect on the NT immunoassay (see Figure 4). Significant changes were observed in both the $\mathrm{IC}_{50}$ value and the maximal absorbance of the assay. The best sensitivity was recorded at the PBS concentration of $0.01 \mathrm{M}$. 


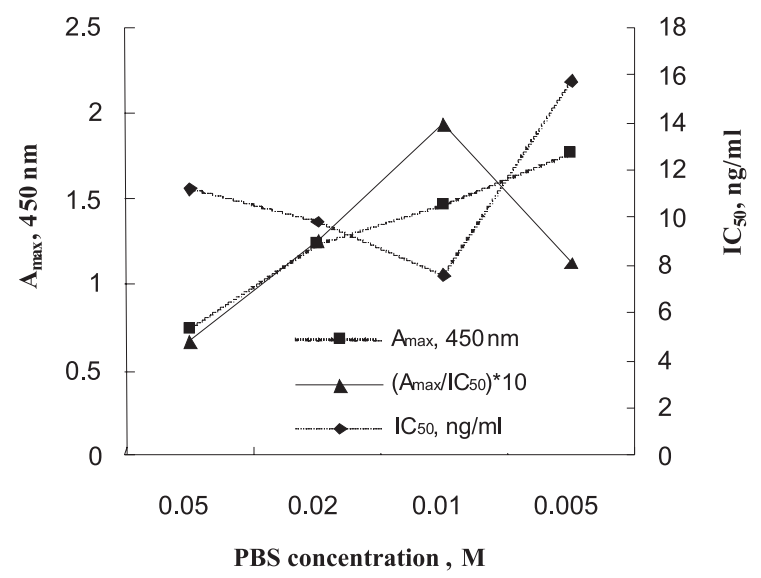

Figure 4. Influence of the length of the ionic strength on $\mathrm{IC}_{50}$ and $\mathrm{A}_{\max }$ of the NT immunoassay

Concentration below this value $(0.005 \mathrm{M}$ of PBS), showed a clear increase of the $\mathrm{IC}_{50}$ and. In contrast, concentrations above $0.01 \mathrm{M}(0.02$ and $0.05 \mathrm{M}$ of PBS) inhibited the assay by drastically reducing the absorbance. The salts would thus compete with the antibody, establishing electrostatic interactions with the analyte and consequently diminishing the detectability of the assay.

To evaluate this effect, antibody dilution buffer were prepared at $\mathrm{pH}$ values varying from 2.5 to 10.5. As it is shown in Figure 5, the best $\mathrm{A}_{\max } / \mathrm{IC}_{50}$ ratio was obtained at $\mathrm{pH}$ around 7.5. Below $\mathrm{pH} 7.5$, the maximum absorbance decreased and at $\mathrm{pH} 2.5$ reached a value as low as around 0.05 units. At $\mathrm{pH}$ values higher than 8.5 , the absorbance also decreased, however, although the maximal absorbance at $\mathrm{pH} 10.5$ was of 0.7 units only, it was still possible to observe a competitive assay with good sensitivity. The $\mathrm{pH}$ value may affect the ionization, not only of the

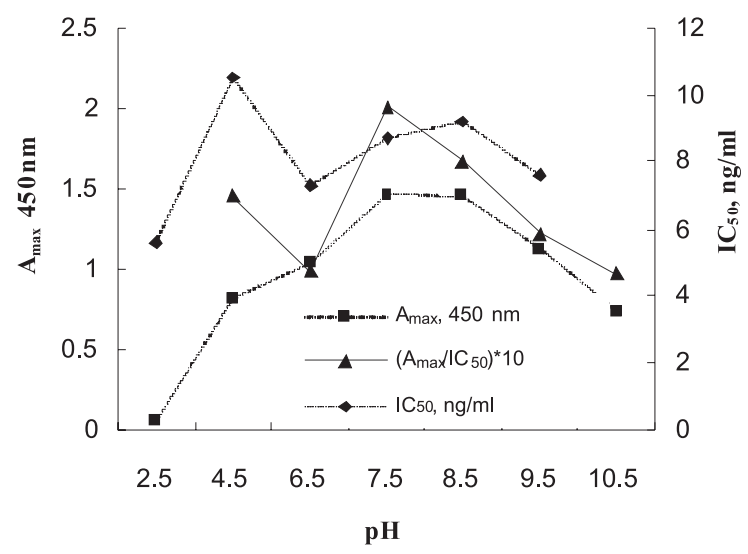

Figure 5. Influence of the length of the $\mathrm{pH}$ on $\mathrm{IC}_{50}$ and $\mathrm{A}_{\max }$ of the NT immunoassay 
analyte, but also of other immunoreactive species participating in the competitive ELISA. As a result, noncovalent interactions such as hydrogen bonding or electrostatic interactions, that stabilize the immunocomplexes will be affected and subsequently influence the immunoassay sensitivity.

Tween 20 is a non-ionic detergent commonly used in immunoassay techniques to reduce non-specific bindings. Figure 6 showed the variation of the $\mathrm{IC}_{50}$ and maximal

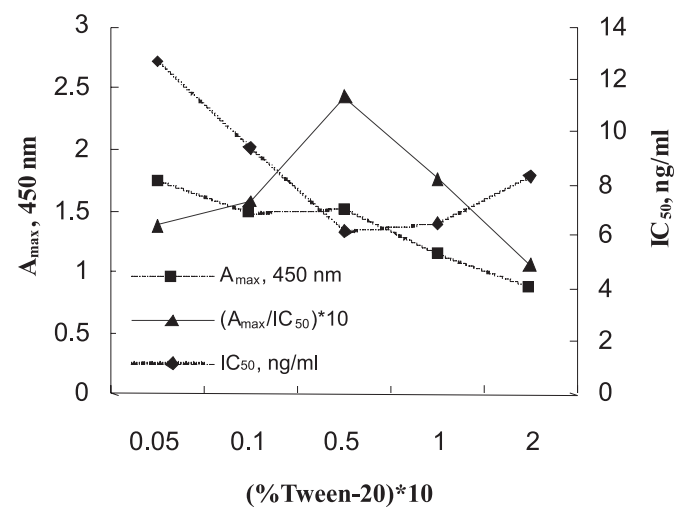

Figure 6. Influence of the detergent Tween 20 on $\mathrm{IC}_{50}$ and $\mathrm{A}_{\max }$ of the NT immunoassay

absorbance of the immunoassay when varying the concentration of this component of the buffer. The best $\mathrm{A}_{\text {max }} / \mathrm{IC}_{50}$ ratio was obtained when using a buffer containing $0.05 \%$ Tween 20 . Below this concentration the absorbance varied slightly, but when exceeding this concentration the absorbance of the assay decreased drastically.

To evaluate this effect, the diluted serum and NT standard solutions were added and incubated in each well at different volume ratio $(70 / 30,60 / 40,50 / 50,40 / 60$, $30 / 70, \mathrm{v} / \mathrm{v}, 100 \mu \mathrm{l} / \mathrm{well})$. As it was shown in Figure 7, a clear decrease of the $\mathrm{IC}_{50}$ and of the maximum absorbance was observed when varving the volume ratio

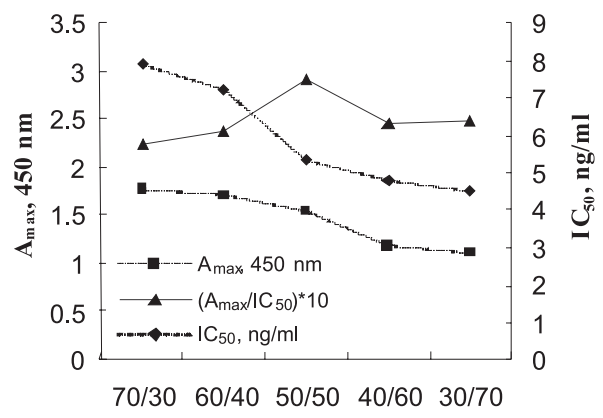

Volume ratio of the diluted serum to NT standard $(\mathrm{v} / \mathrm{v})$

Figure 7. Influence of the volume ratio of the diluted serum to NT standard (v/v) on $\mathrm{IC}_{50}$ and $\mathrm{A}_{\max }$ of the NT immunoassay 
from $70 / 30$ to $30 / 70$. The best $\mathrm{Amax} / \mathrm{IC}_{50}$ ratio was obtained at the volume ratio around 50/50, which was chosen to establish the final immunoassay protocol.

The goat anti-rabbit IgG, conjugated to HRP was diluted with antibody dilution buffer at different concentrations $(1 / 1000,1 / 2000,1 / 3000,1 / 5000,1 / 8000$, v/v). Figure 8 showed the variation of the $\mathrm{IC}_{50}$ and maximum absorbance of the immunoassay when varying the concentration of this antibody. The maximum absorb-

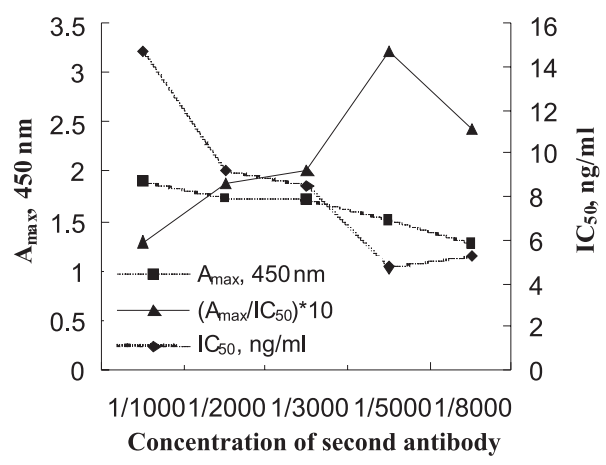

Figure 8. Influence of the concentration of second antibody on $\mathrm{IC}_{50}$ and $\mathrm{A}_{\max }$ of the NT immunoassay

ance has a clear decrease when reducing the concentration from $1 / 1000$ to $1 / 8000$, while the values of $\mathrm{IC}_{50}$ were decrease by the ratio, too. The best $\mathrm{A}_{\max } / \mathrm{IC}_{50}$ ratio was obtained at the concentration 1/5000 and was chosen to establish the final immunoassay protocol.

To evaluate this effect, the mixtures of chromogen and substrate were added and incubated in each well at different volume ratio $(1 / 3,1 / 5,1 / 8,1 / 10,1 / 12$, $\mathrm{v} / \mathrm{v}, 100 \mu \mathrm{l} /$ well). As it was shown in Figure 9, the $\mathrm{IC}_{50}$ showed a clear increase when varying the volume ratio from $1 / 3$ to $1 / 12$ but the absorbance was reduced,

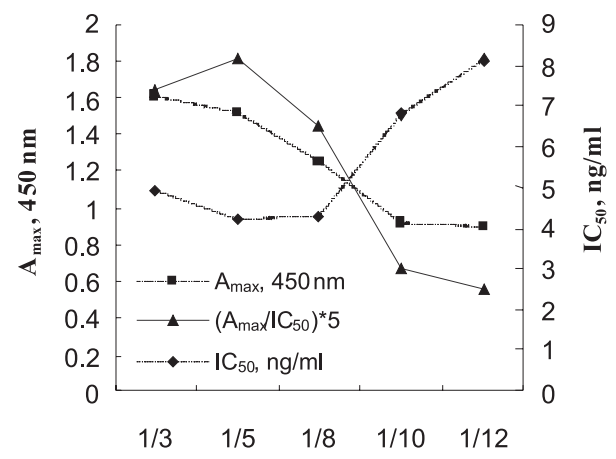

Volume ratio of chromogen to substrate , v/v

Figure 9. Influence of the volume ratio of chromogen to substrate $(\mathrm{v} / \mathrm{v})$ on $\mathrm{IC}_{50}$ and $\mathrm{A}_{\max }$ of the NT immunoassay 
simultaneously. The best $\mathrm{A}_{\max } / \mathrm{IC}_{50}$ ratio was obtained at the volume ratio around $1 / 5$, which was chosen to establish the final immunoassay protocol.

The effect of competitive time was evaluated at different reaction time $(5,10$, 15,30 and $60 \mathrm{~min}$ ). The immunoassay features were readily influenced by the chromogenic reaction step. Figure 10 showed the variation of the $\mathrm{IC}_{50}$ and the maximal absorbance under the investigated conditions. The best sensitivities were obtained with short incubation periods for this step. An increase of the $\mathrm{IC}_{50}$ value was observed when prolonged the length of this step. As it can be observed in the Figure 10, 15 min of incubation was sufficient for an adequate sensitivity of the assay without diminishing the signal.

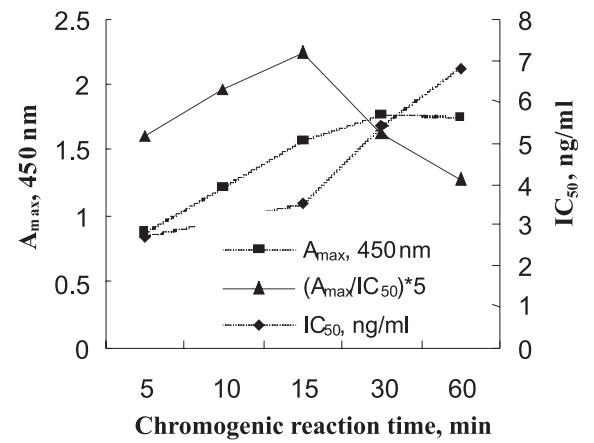

Figure 10. Influence of the length of the chromogenic reaction step on $\mathrm{IC}_{50}$ and $\mathrm{A}_{\max }$ of the NT immunoassay

Under optimum physicochemical conditions, a typical competitive displacement binding curve of NT was shown in Figure 11. The binding curves analysed by immunoassay reported here had an $\mathrm{IC}_{50}$ of $3.5 \mathrm{ng} / \mathrm{ml}$, and the working range was placed between 0.1 and $25 \mathrm{ng} / \mathrm{ml}$. The standard curve was:

$$
y=-0.3194 x+1.6316, R^{2}=0.9927
$$

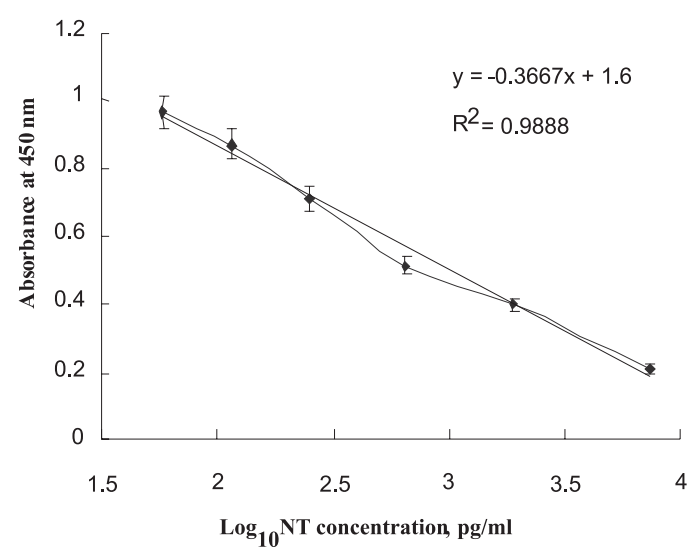

Figure 11. Calibration curve obtained for NT using optimized ELISA 
The maximum signal of the assay was always around 1.5 units of absorbance. The sensitivity reached by this immunoassay proved sufficient for analysing samples and superior to the previously reported immunoassay for NT (Cooper et al., 1998).

The optimized immunoassay was evaluated to determine its selectivity by five structurally related steroids (testosterone, medroxyprogesterone, epitestosterone, progesterone and dehydroepiandrosterone). The results of the cross-reactivity studies were shown in Table 1. It can be observed that in spite of the important chemical similarities between the immunogen and steroids, the specificity of this assay was really high. From the five compounds evaluated, only two were slightly recognized. The rest of the compounds showed insignificant cross-reactivity demonstrating a high specificity of this assay.

Table 1. Cross reactivity of NT antiserum with its structurally related steroids

\begin{tabular}{lc}
\hline Compounds & Cross-reaction, \% \\
\hline 19-Nortestosterone & 100 \\
Testosterone & 1.3 \\
Medroxyprogesterone & 0.1 \\
Androstenedione & $<0.1$ \\
Epitestosterone & $<0.1$ \\
Dehydroepiandrosterone & $<0.1$ \\
16, 17-Dihydronortestosterone & $<0.1$ \\
Norepitestosterone & $<0.1$ \\
Progesterone & $<0.1$ \\
\hline
\end{tabular}

The intra-assay precision of the analytical method was evaluated by analysing five times inside a plate, and the samples spiked with NT at different concentration levels.

Similarly, these samples were analysed on different days using the same protocol to obtain the precision between different assays. Table 2 showed the results obtained from these experiments. It can be observed that the intra-assay and

Table 2. Intra-assay and inter-assay precision and accuracy for NT determination in spiked samples

\begin{tabular}{lccccrcc}
\hline Spiked & \multicolumn{3}{c}{ Intra-assay, $\mathrm{n}=5$} & & \multicolumn{3}{c}{ Inter-assay, $\mathrm{n}=5$} \\
\cline { 2 - 4 } \cline { 6 - 8 } $\begin{array}{l}\text { amount } \\
\mathrm{ng} / \mathrm{ml}\end{array}$ & mean $\pm \mathrm{SD}$ & $\mathrm{CV}, \%$ & recovery, \% & & mean $\pm \mathrm{SD}$ & $\mathrm{CV}, \%$ & recovery, \% \\
\hline 1 & $1.05 \pm 0.055$ & 8.5 & 104.68 & & $0.96 \pm 0.08$ & 13.4 & 96.4 \\
5 & $4.06 \pm 0.126$ & 5.2 & 79.3 & & $3.83 \pm 0.215$ & 9.3 & 76.9 \\
\hline
\end{tabular}

the inter-assay coefficients of variation are 5.2 and $9.3 \%$ when measuring around the middle point of the standard curve. The values were a bit higher if measurements take place at the limits of the working range of the assay, but always the co- 
efficients of variation obtained were below $15 \%$. The accuracy was evaluated by adding known amounts of standard NT dose ( 1 and $5 \mathrm{ng} / \mathrm{g}$ ) to bovine tissue samples and compared the measured value by the optimized ELISA with the recovery values calculated. Table 2 showed the recoveries obtained at different concentration levels. It can be observed that the accuracy ranged from 76.9 to $104.68 \%$ at different NT concentrations spiked samples. The recovery values were a bit low if measurements take place at the high concentrations spiked.

\section{CONCLUSIONS}

A fast, easy to perform, sensitive and specific polyclonal antibody-based enzymelinked immunosorbent assay (ELISA) for the measurement of nortestosterone has been developed and optimization. The strategy used in this paper is to develop an immunoassay that improving the immunoassay sensitivity. The assay enables to process a large number of samples within a short period of time and does not require highly skilled personnel. This immunoassay can complement chromatography techniques in field assay conditions and screening procedures, nevertheless, more studies should be performed for its application in commercialization.

\section{REFERENCES}

Bruggeman V., Room G., Vanmontfort D., Verhoeven G., Decuypere E., 2003. Effect of embryonic 19-nortestosterone treatment and surgical bursectomy on plasma concentrations of reproductive hormones, on inhibin content in adrenals and gonads and on the histological appearance of the gonads in the young chicken. Gen. Comp. Endocrinol. 131, 106-116

Cooper J., Currie W., Elliott C.T., 2001. Comparison of the efficiences of enzymatic and chemical hydrolysis of (nortestosterone and diethylstilboestrol) glucuronides in bovine urine. J. Chromatogr. B 757, 221-227

Cooper J., Elliott C.T., Baxter G.A.,Hewitt S.A., McEvoy J.D.G., McCaughey W.J., 1998. Comparison of two polyclonal antibodies for the detection of 19-nortestosterone in bovine bile by ELISA. Food Agric. Immunol. 10, 133-142

Degand G., Schmitz P., Maghuin-Rogister G., 1989. Enzyme immunoassay screening procedure for the synthetic anabolic estrogens and androgens diethylstilbestrol, nortestosterone, methyltestosterone and trenbolone in bovine urine. J. Chromatogr. 489, 235-243

Draisci R., Palleschi L., Ferretti E., Lucentini L., Cammarata P., 2000. Quantitation of anabolic hormones and their metablites in bovine serum and urine by liquid chromatography-tandem mass spectrometry. J. Chromatogr. A 870, 511-522

Evrard P., Gaspar P., Maghuin-Rogister G., 1986. A specific radioimmunoassay for the detection of 19-nortestosterone residues in urine and plasma of cattle. J. Immunoassay 7, 353-363

Hobbs C.J., Jones R.E., Plymate S.R., 1996. Nandrolone, a 19-nortestosterone, enhances insulinindependent glucose uptake in normal men. J. Clin. Endocrinol. Metab. 81, 1582-1585 
Kim J.Y., Choi M.H., Kim S.J., Chung B.C., 2000. Measurement of 19-nortestosterone and its esters in equine plasma by high performance liquid chromatography with tandem mass spectrometry. Rapid Commun. Mass Spectrom. 14, 1835-1840

Kohler R.M.N., Lambert M.I., 2002. Urine nandrolone metabolites: false positive doping test? Brit. J. Sport. Med. 36, 325-329

Kuhnz W., Gieschen H., 1998. Predicting the oral bioavailability of 19-Nortestosterone progestins in vivo from their metabolic stability in human liver microsomal preparations in vitro. Drug Metab. Disposition 26, 1120-1127

Le Bizec B., Gaudin I., Monteau F., André F., Impens S., De Wasch K., De Brabander H., 2000. Consequence of boar edible tissue consumption on urinary profiles of nandrolone metabolites. I. Mass spectrometric detection and quantification of 19-norandrosterone and 19-noretiocholanolone in human urine. Rapid Commun. Mass Spectrom. 14, 1058-1065

Le Bizec B., Monteau F., Gaudin I., André F., 1999. Evidence for the presence of endogenous 19norandrosterone in human urine. J. Chromatogr. B 723, 157-172

Marcos V., Perogordo E., Espinosa P., Mart'in De Pozuelo M., Hooghuis H., 2004. Multiresidue analysis of anabolic compounds in bovine hair by gas chromatography tandem mass spectrometry. Anal. Chim. Acta 507, 219-227

Meriggiola M.C., Farley T.M.M., Mbizvo M.T., 2003. A review of androgen-progestin regimens for male contraception. J. Andrology 24, 466-483

Oubina A., Ballesteros B., Galve R., Barcelo D., Marco M.-P., 1999. Development and optimization of an indirect enzyme-linked immunosorbent assay for 4-nitrophenol. Application to the analysis of certified water samples. Anal. Chim. Acta 387, 255-266

Reznik Y., Dehennin L., Coffin C., Mahoudeau J., Leymarie P., 2001. Urinary nandrolone metabolites of endogenous origin in man: a confirmation by output regulation under human chorionic gonadotropin stimulation. J. Clin. Endocrinol. Metab. 86, 146-150

Robinson N., Taroni F., Saugy M., Ayotte Ch., Mangin P., Dvorak J., 2001. Detection of nandrolone metabolites in urine a football game in professional and amateur players: a Bayesian comparison. Forensic Sci. Int. 122, 130-135

Roda A., Manetta A.C., Portanti O., Mirasoli M., Guardigli M., Pasini P., Lelli R., 2003. A rapid and sensitive 384-well microtitre format chemiluminescent enzyme immunoassay for 19nortestosterone. Luminescence 18, 72-78

Van Look L.J., Jansen E.H., Van Den Berg R.H., Zomer G., Vanoosthuyze K.E., Van Peteghem C.H., 1991. Development of a competitive enzyme immunoassay for 17 alpha-19- nortestosterone. J. Chromatogr. 564, 451-459 